\title{
Growth rate variability of larval European eels (Anguilla anguilla ) across the extensive eel spawning area in the southern Sargasso Sea
}

\author{
Ayala, Daniel Jiro; Munk, Peter
}

Published in:

Fisheries Oceanography

Link to article, DOI:

10.1111/fog. 12273

Publication date:

2018

Document Version

Peer reviewed version

Link back to DTU Orbit

Citation (APA):

Ayala, D. J., \& Munk, P. (2018). Growth rate variability of larval European eels (Anguilla anguilla) across the extensive eel spawning area in the southern Sargasso Sea. Fisheries Oceanography, 27(6), 525-535.

https://doi.org/10.1111/fog.12273

\section{General rights}

Copyright and moral rights for the publications made accessible in the public portal are retained by the authors and/or other copyright owners and it is a condition of accessing publications that users recognise and abide by the legal requirements associated with these rights.

- Users may download and print one copy of any publication from the public portal for the purpose of private study or research.

- You may not further distribute the material or use it for any profit-making activity or commercial gain

- You may freely distribute the URL identifying the publication in the public portal

If you believe that this document breaches copyright please contact us providing details, and we will remove access to the work immediately and investigate your claim 
1 Growth rate variability of larval European eels (Anguilla anguilla) across the extensive eel 2 spawning area in the southern Sargasso Sea

3 Daniel Jiro Ayala, Peter Munk*

4 National Institute of Aquatic Resources, Technical University of Denmark, 2800 Lyngby, Denmark

$5 \quad$ *Corresponding author. E-mail address: pm@aqua.dtu.dk

\section{Abstract}

The European eel (Anguilla anguilla) spawns in the Sargasso Sea, and the leptocephalus larvae are

9 distributed in the Subtropical Convergence Zone (STCZ), covering an area approximately $500 \mathrm{X}$

$102000 \mathrm{~km}$ in extent. The STCZ is hydrographically diverse and highly dynamic, which is likely to

11 impact growth and survival opportunities of the larvae. Here we investigate the temporal and spatial

12 growth rate variability of larvae collected along seven sampling transects across the STCZ during

13 March-April 2014. Scanning electron microscopic analyses of otolith ring-formations were used to

14 estimate larval age-at-length, initial growth and growth trajectories. Analyzed larvae averaged 14

$15 \mathrm{~mm}$ in length and 30 days of age. Age estimation indicated that the larvae were spawned during one

16 continuous period, extending from mid-February to late-March, and that spawning had peaked

17 during the new moon of March 4. Growth estimates (average: $0.38 \mathrm{~mm} \mathrm{~d}^{-1}, \sim 6 \%$ weight increase $\mathrm{d}^{-}$

$18{ }^{1}$ ) showed substantial variability among individuals. There were no apparent spatial trends in this

19 variability, and no linkage to measures of temperature and salinity, while earlier-spawned

20 leptocephali showed slightly higher growth rates than later-spawned larvae. The variability in

21 growth rates at single sampling sites was as great as variability across the entire area of distribution.

22 This indicates that individual growth opportunities are strongly impacted by variable conditions in 
23 the immediate environment while average conditions for larval growth and survival are basically

24 the same throughout the immense area of larval distribution.

25 Running title: Growth rate variability of eel larvae

26 Keywords: Anguillid eels, Subtropical Convergence Zone, temporal and spatial variability, specific 27 growth rate, otolith microstructure, spawning period, new moon.

\section{Introduction}

The European eel, Anguilla anguilla, is an important fisheries species and has significant public and

31 scientific interest. There are still several unknown aspects of its life cycle, especially during the early life history. The hatched larvae transform to a transparent, elongated "willow-leaf" form

33 (termed a leptocephalus) shortly after their yolk sac is exhausted, and they stay in that stage for an 34 extended period (Miller, 2009). The European eel spawns in the Sargasso Sea and its leptocephali 35 drift across the North Atlantic toward adult habitats on the European and North African continents 36 (Tesch, 2003). During the larval period, they obtain lengths of approximately $7-8 \mathrm{~cm}$, but then shrink to 6-7 $\mathrm{cm}$ when metamorphosing to a juvenile, glass-eel form, before entering estuarine and freshwater habitats where they transform into yellow eels. Years later another transformation takes place; the eels attain larger eyes and a silvering of the skin (Pankhurst, 1982; Tesch, 2003), whereupon they start a spawning migration back to the Sargasso Sea (Aarestrup et al., 2009;

41 Amilhat et al., 2016).

42 The spawning takes place in an extensive, hydrographically characteristic area of the southern

43 Sargasso Sea (Schmidt, 1925; Schabetsberger et al., 2016) termed the Subtropical Convergence 44 Zone (STCZ). It is approximately located between $70^{\circ}$ and $50^{\circ} \mathrm{W}$, and is bounded latitudinally by 
seasonally shifting frontal zones, generally around $24^{\circ}$ and $28^{\circ} \mathrm{N}$ (Schmidt, 1922, 1925; Miller et al., 2015). Nutrient entrainment is enhanced in this zone due to strong eddy activity (Richardson \& Bendtsen, 2017), providing an increase in primary production and zooplankton abundance that likely enhances growth conditions for the eel larvae (Munk et al., 2010; Andersen et al., 2011; Riemann et al., 2011).

Insight into larval eel growth variability is a requisite for understanding the bio-physical linkages influencing their life traits in this oligotrophic, open-ocean environment. Their growth rates have historically been estimated from changes in average body sizes between sampling dates (Schmidt 1922, 1935; Boëtius \& Harding, 1985), but this procedure does not provide sufficient precision and resolution due to infrequent and incomplete sampling across the relevant areas of distribution (Shinoda et al., 2011). Alternatively, growth rates have been ascertained from ageing of larvae by microstructure analysis of their otoliths, either during their earlier stages, when they are distributed in the southern Sargasso Sea (Castonguay, 1987; Kuroki et al., 2017), or from metamorphosed (glass) eels caught in brackish or freshwater environments close to the European continent (Lecomte-Finiger, 1992; 1997; Arai et al., 2000; Wang \& Tzeng, 2000). The glass-eel method, however, suffers from uncertainties in the interpretation of peripheral ring patterns, because the colder environment experienced during this stage might have depressed ring formation (Fukuda $e t$ al., 2009).

Based on otolith microstructure analysis and age-at-length estimations, we here describe and analyze the temporal and spatial growth variability of European eel larvae during their first months after hatching, when they are widely distributed across the southern Sargasso Sea. The study was part of a research initiative, named the Danish Eel Expedition 2014, which focused on environmental conditions and early life characteristics of the European eel larvae in the Sargasso Sea. Given the large hydrodynamic variability at both local and regional scales throughout the area 
69

70

71

72

73

74

75

76

77

78

79

80

81

82

83

84

85

86

87

88

89

90

91

of young leptocephalus distribution, our objective was to ascertain whether some spawning areas or periods were potentially more favorable than others for larval growth. Further we wanted to evaluate the length of the spawning period and relate the timing of peak spawning activity to phases of the moon (ref. "New Moon Hypothesis," Tsukamoto et al. (2003).

\section{MATERIAL AND METHODS}

\section{Larval collection and identification}

Leptocephali larvae were sampled at 72 Stations from 16 March to 20 April 2014, from the research vessel DANA (Technical University of Denmark) (Fig. 1, Table 1). Nine latitudinal transects were sequentially sampled from west to east, and collections were used to examine leptocephalus abundance and provide specimens for further analysis. The larvae were sampled with a $3.5 \mathrm{~m}$ diameter, ring net, equipped with a $25 \mathrm{~m}$ long, $560 \mu \mathrm{m}$ mesh net, with $300 \mu \mathrm{m}$ mesh in the hindmost $1 \mathrm{~m}$ of the net and in the cod-end container. Larval sampling was conducted during both daytime and nighttime. At a ship speed of 2.5 knots, the net was hauled obliquely to a maximum depth of $200 \mathrm{~m}$. Flowmeters in the opening measured water flow into the net.

On board, leptocephali were immediately sorted fresh from the plankton, and screened for presence of European and American eel larvae using myomere counts of the body (A. anguilla $\geq 112, A$. rostrata $\leq 111$ ) in conjunction with the position of the last dorsally directed blood vessel (at myomere number: A. anguilla 46-50, A. rostrata 44-48). The standard length (SL, see Sørensen et al. 2016) of potential Anguilla larvae were measured to the nearest $0.1 \mathrm{~mm}$ and larvae were digitally photographed, before being individually stored in $96 \%$ ethanol for later genetic species identification. Remaining plankton samples from each station were also stored in $96 \%$ ethanol, and re-examined post-cruise for Anguilla larvae that were missed during the initial screening. Thirty 
larvae selected from the first-screening were measured before being preserved in ethanol for later re-measurement and calculation of a shrinkage factor (relationship: fresh length $(\mathrm{mm})=1.163 *$ preserved length $\left.(\mathrm{mm})-4.356, \mathrm{r}^{2}=0.997\right)$. Lengths (SL) of the A. anguilla larvae found during screening, of the preserved sample, where subsequently converted to the lengths of newly caught larvae using the shrinkage regression. For calculation of weight specific growth rates, we used a regression based on leptocephali of several species measured and weighed by Deibel et al. (2012) (relationship: Wet weight $(\mathrm{g})=1.3 \times 10^{-5} \mathrm{SL}^{2.34}(\mathrm{~mm})$ ).

Genetic species-identity confirmation of all anguillid larvae, differentiating among European eels, American eels and their hybrids, was carried out based on analysis of the mitochondrial cytochrome $b$ gene and microsatellite genotyping (see Jacobsen et al., 2016).

\section{Scanning electron microscopic analysis (SEM)}

A subset of the genetically-confirmed European eel leptocephali was selected for otolith microstructure analysis. Leptocephali were subsampled ensuring a representative coverage from each station where European eel leptocephali were caught. The sagittal otoliths were extracted using acupuncture needles under a dissecting microscope, and embedded in epoxy resin (Epofix®; Struers, Copenhagen, Denmark) on glass slides. Otoliths were hand polished to the core using a succession of fine-grained silicon carbide/aluminum oxide polishing papers (3M®; St.Paul,

109 Minnesota, USA - final grain size 0.3 microns).

110 Other studies on eel larvae have shown the increment widths of the individual daily growth rings to

111 be below the resolving capability of light microscopy, around $200 \mathrm{~nm}$ (e.g. Castonguay, 1987; Arai 112 et al., 1999; Kuroki et al., 2017). Therefore, we examined all otoliths with scanning electron 113 microscopy (SEM) that resolves spatially to $\sim 1 \mathrm{~nm}$ (Goodhew et al., 2000). To prepare the 114 mounted and polished otoliths for SEM, they were etched with $0.05 \mathrm{M} \mathrm{HCl}$ for approximately 20 
115

seconds and coated with gold in an ion-sputterer. Subsequently, high-resolution digital pictures of each otolith were made using an FEI Quanta FEG 650 scanning electron microscope and stored for later analysis. Analysis of the left otolith was always attempted first; if no good-quality pictures could be made of it, the right otolith was used. Some otoliths required subsequent re-polishing and re-imaging when the initial SEM analysis showed they were not polished to the core. Final SEM photos, in which the magnification range generally was from 5000 to 20000 , were visually inspected and growth increments, defined as alternating darker and lighter ring patterns, were counted. A range of measurements was made on the otoliths (see below).

An inner heavy, dark ring circumscribing the nucleus was regarded as the hatch check $(\mathrm{HC}$; Umezawa et al., 1989) and was used to delineate the nucleus (Fig. 2). A crystalline crown (CC; Shinoda et al., 2004) region could be seen surrounding the hatch check. This ended in another heavy, dark zone, which often was composed of two distinct and more heavily imprinted rings immediately adjacent to each other. We refer to this second characteristic pattern as the first-feeding check (FFC, Fig. 2; Shinoda et al., 2004), and we assume the FFC demarcates the start of exogenous feeding (Lecomte-Finiger, 1992; Shinoda et al., 2004). The region within the FFC will be referred to as the core region. In some instances isolated and unclear ring patterns could be seen within the radius of the crystalline crown; these were not included in the estimate of total number of rings. Only the concentric growth increments from the FCC (inclusive) to the otolith edge were counted and interpreted as individual growth increments. (Fig. 2). Measurements were carried out of maximal otolith diameter, nucleus diameter, core region diameter, as well as the accumulated widths of the first 10 and the total number of growth increments. All measurements were made along each otolith's longest radius (core to edge).

\section{Age and growth estimations}


138 The number of growth rings outside the FCC was assumed to represent the age of larvae in days 139 from first feeding (see discussion for arguments for this assumption). In order to estimate age from 140 spawning, we added 14 days to account for a 2-day embryonic period (Sørensen et al., 2016, Politis 141 et al 2017) and a 12-day post-hatch period (at assumed optimal temperature of $18 \mathrm{C}$ ) before a larva 142 would be capable of exogenous feeding (Politis et al 2017). Spawning dates (date of fertilization) 143 were back-calculated by subtracting the age estimate from the date of capture of each individual. A 144 "spawning curve" was obtained showing frequency of larvae along a "day of hatch" axis, and it was 145 subsequently adjusted to account for differences in accumulated mortality among differently aged 146 larvae and to account for the under-representation of the late-spawned larvae that were not available 147 to the gear during our first period of sampling. In the first case we incorporate an arbitrarily set 148 mortality rate of $10 \% \mathrm{~d}^{-1}$, in the latter case the frequency of larvae from each sampling date was 149 weighted by the inverse number of stations where larvae from that date could be covered by our 150 station sampling.

151 Growth rates were expressed in three ways. First, estimates of absolute and specific growth rates for 152 the entire population were made using all length-at-age information and regressing those data by 153 non-linear fitting to the Laird-Gompertz growth function (Laird, 1969). Second, as the relationship 154 between larval length and age appeared approximately linear for larvae below $25 \mathrm{~mm}$, we assumed 155 linear growth in that range and estimated individual growth rates from IGR $=(\mathrm{SL}-\mathrm{LH}) * \mathrm{ADPH}{ }^{-1}$, 156 where LH is the mean length at hatching (set to $3.6 \mathrm{~mm}$, Sørensen et al., 2016), and ADPH is age at 157 hatching (set to increment number plus 12). Lastly, to assess temporal differences in growth 158 (earlier-spawned versus later-spawned leptocephali), we used the apparent relationship between 159 otolith growth (ring widths) and increase in larval length to define an index of initial growth rate 160 (IGI) as the width of the initial 10 otolith increments (when at least 10 increments after FFC were 161 apparent). 
163 CTD casts by a Seabird SBE11 (9+) were carried out at all stations of sampling, from surface to 400

$164 \mathrm{~m}$. Measures of temperature and salinity at depths $50 \mathrm{~m}$ and $150 \mathrm{~m}$, which are the depth strata where 165 larvae are found aggregating at night and day, respectively (Castonguay and McCleave 1987; Munk 166 et al. in prep), were used for analyses of linkages between growth estimates and oceanography. For 167 illustration of basic oceanographic characteristics in the sampling area measures were spatially 168 interpolated by the nearest-neighbor method in the program Surfer $\odot$.

\section{RESULTS:}

170 European eel larvae were collected at 52 stations along the first seven transects (Table 1); no larvae 171 were found at stations along transects 8 or 9 (along $44^{\circ} 00^{\prime} \mathrm{W}$ and $37^{\circ} 40^{\prime} \mathrm{W}$, respectively, Fig. 1a). 172 Larval lengths (SL) ranged from 6-20 mm, except for seven larvae of 21-26 mm and a single larva 173 of $34.2 \mathrm{~mm}$. Larval mean lengths at different stations showed large spatial variation, but there were 174 no general spatial trends (Fig. 1b). However, patterns along specific transects differed to some 175 extent: along transects 1, 2, 4 and 5 mean lengths showed a slight increase toward the more 176 northerly stations, whereas the opposite tendency was seen along transects 3, 6 and 7.

177 The temperature measured at 50m and $150 \mathrm{~m}$ depth are contoured in Fig. 1b, c. The gradients in 178 temperature change illustrate the significant hydrographic variability in the area; temperature 179 decrease from south to north on each transect and the steep change in temperature (frontal zone) is 180 positioned differently, dependent on depth of measurement. Larvae are in many cases sampled 181 across the frontal zone(s). 
183 Preparation for SEM-imaging was carried out on sagittal otoliths of 312 of the larvae; however, 89 184 otoliths were rendered unexaminable by combinations of overpolishing, cracking/splintering and over-etching. Thus, 223 had sufficient quality for SEM with a clearly discernible ring increment pattern across a full section from the core to the periphery of the otolith.

Otoliths were generally circular in shape, and in larvae old enough to have begun increment deposition we could see distinctive and clear concentric growth rings circumscribing the bipartite core region (Fig. 2). The core region had an average diameter of $23.5 \pm 2.7 \mu \mathrm{m}$, and was always divided into two subregions: an inner nucleus and a crystalline growth-crown. Most nuclei were roughly circular in shape, but infrequently ( 15\% of otoliths) $2-3$ conglomerated-nuclei resulted in oblong \{nucleus + crystalline crown $\}$ assemblages. The crystalline growth-crown is, according to Shinoda et al (2004), produced in the yolk-sac stage during the first two weeks post-hatch. The individual growth increments outside the defined FFC are composed of a calcium carbonate-rich ring abutting a protein-rich ring. Together these pairs produce a distinctive and characteristic, translucent-opaque concentric ring pattern in SEM after the polishing and etching (LecomteFiniger, 1992, Leander et al., 2013). Only infrequently ( 5\% of otoliths) could ring patterns be distinguished within the FFC. These increments were much fainter relative to the distinct growth increments outside the FCC, and often they did not form a complete ring. Otolith diameters ranged from 22.1 to $132.8 \mu \mathrm{m}$ (Table 1), and these, like the widths of the incremental sections, showed a curvilinear relationship to larval length (Fig. 3). The 223 SEM-analyzed otoliths had an average of 13.7 increments, of these 208 larvae from 7.2$24.7 \mathrm{~mm}$ had from 2-58 growth increments, and 14 larvae in pre-leptocephalus stage and of lengths from 6.3-8.9 mm, had not yet implemented deposition of primary growth. The single, larger $A$. anguilla leptocephalus, had 96 growth increments. Overall the individual growth-rings had an average width of $397 \mathrm{~nm}$ (range: $252-792 \mathrm{~nm}$ ). 
208 Fourteen specimens that did not have primary growth rings and did not show evidence of an FCC

209 were taken to be $\leq 15$ days from spawning, based on our assumption that initial increment deposition 210 begins at the onset of first-feeding, 15 days post-fertilization. The largest $34.2 \mathrm{~mm}$ larva was

211 estimated to 110 days old. Not including it or the 14 no-growth-increment specimens, an average 212 age of 30 days from spawning (range: 17-73 days) was estimated. The largest difference in age 213 between youngest and oldest eel larvae for any single station was 52 days. Average age at given 214 stations (corrected for differences in sampling time) showed some spatial tendencies. Ages 215 increased toward the north along four of the transects, and the larvae in the eastern part of the sampling area were generally younger (spawned later) than those from western parts (Fig. 1c).

217 Estimated spawning dates ranged from $19^{\text {th }}$ January to $28^{\text {th }}$ March (Fig 4a). The single larger 218 specimen had an estimated spawning date of $8^{\text {th }}$ December, 2013. From daily spawning intensity 219 estimates, which considered mortality and uneven sampling coverage of later-hatched larvae (Fig. $2204 \mathrm{~b}$ ), we assessed both mean and medium spawning date to $28^{\text {th }}$ February. The new moon dates in 221 early 2014 over the Sargasso Sea were $31^{\text {st }}$ January, $1^{\text {st }}$ March and $31^{\text {st }}$ March. The spawning 222 intensity of European eels, therefore, appeared to have peaked around the specific new moon event of $1^{\text {st }}$ March 2014.

224 The individual length-at-age estimates showed considerable variability among the larvae 225 investigated, with a length range of $\pm 2.5 \mathrm{~mm}$ for age intervals of 1 day. The large variability was apparent for all sampled larvae (Fig. 5a), and also was observed among specimens from single stations, as exemplified for station 30 (Fig. 5b). For all sampled larvae the relationship between age and length appeared curvelinear, and data were represented by a non-linearly fitted Laird-Gompertz curve (Fig 5a). Growth rates deduced from this curve-fit illustrate their general decline during 
ontogeny, both for absolute growth in length and for length- and weight-specific growth rates

231 (Table 2). For the first part of the growth curve (e.g. SL $<25 \mathrm{~mm}$ ) the relationship does not differ markedly from linear, and we used a linear model (Fig. 5c, rate estimate $0.38 \mathrm{~mm} \mathrm{~d}^{-1}$ ) for a comparison to results from historical growth studies that have used linear regressions in their 234 growth rate estimates.

235 The estimates of individual growth rates (IGR), showed high variability, with neither latitudinal nor 236 longitudinal spatial trends (both tests: $n=223$, p>0.20; Fig. 6 a,b). The growth indices of early larval 237 growth, based on the total widths of the first 10 increments (IGI) showed a variability of the same 238 magnitude and spatial trends in these are either not significant (test of longitude: $n=223, p>0.20$; 239 Fig. 6 c) or showed a weak tendency of decline in northward direction (test of latitude: $\mathrm{n}=223$, $240 \mathrm{P}<0.05$; Fig. 6 d). The statistical tests of potential relationships between growth rate estimates and 241 hydrographic measures, here chosen as temperature and salinity at 50 and $150 \mathrm{~m}$, did neither show 242 significant trends (all IGR tests: $\mathrm{n}=221, \mathrm{p}>0.5$; all IGI tests: $\mathrm{n}=144, \mathrm{p}>0.07$ ). A temporal trend 243 appeared in IGI; when compared to estimated individual hatching dates, these indices of initial 244 growth rates showed a significant decline during the spawning period $(n=147, p<0.05$; Fig. 7). This 245 decline in initial growth rates was also significant for a subset of data which were from a one station 246 only (station $\left.30,62^{\circ} 45^{\prime}, 2^{\circ} 30^{\prime}\right)(n=53, p<0.05)$; subset indicated in Fig. 7).

\section{DISCUSSION:}

\section{Otolith formation}

250 Our analysis of larval eel ages and growth required robust interpretation of otolith characteristics.

251 Particularly important were the points selected as indicative of age, the distinctions among different 
ring types and the measurements of ring widths. Further, the assumption about the temporal (daily) periodicity in increments was essential.

In the majority of our examined otoliths we could ascertain both a hatch check (HC) and a firstfeeding check (FFC) (Fig. 2). The mean diameters of HC and FFC from the present study (10.4 $\mu \mathrm{m}$ and $23.4 \mu \mathrm{m}$, respectively) are in close correspondence to diameters reported by Arai et al. (2000) and Wang \& Tzeng (2000), and our definition of check-marks also appears in good agreement with those described for glass eel otoliths from A. anguilla (Lecomte-Finiger, 1992) and for leptocephali of other species (Shinoda et al., 2004).

The duration from hatching to FFC could not be estimated based on microstructure patterns. Thus,

261 in the back-calculation to an estimated date of spawning, we used a mean duration from hatching to 262 FFC of 12 days from laboratory studies. Laboratory growth trials by Politis et al 2017 showed time to first feeding of 12 days post-hatching at $18^{\circ} \mathrm{C}$, and biomechanical modeling studies (Bouilliart et al., 2015) likewise indicate that $A$. anguilla leptocephali are capable of transitioning from endogenous nutrition to exogenous feeding at 12-13 days post-hatching. The estimate we used from the study by Politis et al. (2017) was obtained at the temperature which these find optimal for larval 267 development. At suboptimal, but viable, temperatures, 16 and $20^{\circ} \mathrm{C}$ the durations are 14 or 10 days 268 respectively (Politis et al. 2017), thus our mean spawning date could vary \pm 2 days, dependent on 269 assumed temperature.

270 Ring widths in otoliths from larvae of anguillid eel species are generally very narrow, below the 271 resolution of light microscopy (Kuroki et al., 2014), so we used SEM for adequate resolution of 272 ring patterns. In otoliths that have been properly ground and etched, the rings were distinct as a 273 sequence of alternating darker and brighter bands. Most studies of increments in the otolith 274 anguillid larvae have been carried out on the larger otoliths from glass eels caught when they have 
returned to their respective continents. Incremental growth zones of glass eel otoliths are often diffuse, zones apparently formed during metamorphosis or during sustained periods in lowertemperature waters (Arai et al., 2000; Cieri \& McCleave, 2001, Fukuda, 2009). However, within the eel's larval period, as examined in the present investigation, we expect warmer, weakly variable, environmental conditions, and thus a generally consistent deposition patterns.

It is imperative for our interpretation of age, that the otolith growth increments are produced daily. Daily growth ring deposition has been validated for four anguillids: two tropical species, $A$. mormorata (Sugeha et al., 2001) and A. celebesensis (Arai et al., 2000), and two temperate species, A japonica (Umezawa et al., 1989; Shinoda et al., 2004) and A. rostrata (Martin, 1995). It appears that daily periodicity in ring deposition is a common trait among anguillid larvae. The periodicity of increments in otoliths of $A$. anguilla has not yet been validated experimentally, owing to difficulties in rearing their larvae beyond first-feeding (Tomkiewicz et al., 2013; Sørensen et al., 2016). Nevertheless, we assume daily ring formation in A. anguilla for two reasons: (1) overall otolith microstructure is closely similar among many eel species (Correia et al., 2002; Lee et al., 2008; Kuroki et al. 2008), including both tropical and temperate anguillids (Leander et al., 2013). (2) Studies by Correia et al. (2002) and Ma et al. (2005) suggest that leptocephali from regions with relatively warm water, as was the case with specimens in the current study, do have daily otolith increment deposition.

\section{Age estimates}

The present estimates of leptocephalus ages showed high variation at given sampling sites (stations), for example larvae at one station had a more than 50-day age range from youngest to oldest individuals. Castonguay (1987) showed a comparably great age range for A. anguilla, specifically 46 days at a single of his sampling stations. These variably-aged groups of leptocephali 
are not likely to have actively traversed the distances between our sampling stations within the relevant periods of time; they were apparently spawned over extended periods in basically the same water masses. As we see this pattern throughout the vast geographical area of our sampling, the observations imply that spawning is wide-spread in space and time. Thus spawning in the area might not take place as synchronized events by large assemblies of eels, a more individual behavior is indicated by the laboratory observations by Boëtius and Boëtius (1980) of courtship by male A.anguilla towards individual females. Further, individual female eels have been shown to spawn several batches of eggs over time (Tomkiewicz \& Jarlbæk, 2008), and the larvae from relatively narrow areas could likely stem from such series of separate egg batches spawned by the individual females.

The spawning curve estimated from findings of the present study did not support the new moon hypothesis of spawning as it has been formulated for A. japonica; i.e. with a restricted spawning 310 event during a few days around new moon (Ishikawa et al., 2001; Tsukamoto 2006, 2009).

311 According to our estimation, the spawning took place during an extended period, however, the 312 median of the spawning curve was close to new moon, and some synchronicity, where the intensity 313 of spawning is inversely related to lunar light intensity, cannot be precluded. Our findings in respect 314 to ages of sampled larvae suggest that the earliest spawning in 2014 took place around mid315 February. If there had been spawning earlier in 2014, we would have expected to find some older 316 leptocephali during our investigation. There might, however, be later spawning episodes 317 potentially related to lunar periodicity - which we did not cover during our period of sampling. 318 Prior field collections of small A. anguilla in the Sargasso Sea have indicated spawning throughout 319 the early half of the year (Kleckner \& McCleave, 1988; McCleave \& Kleckner, 1987).

\section{Growth estimates}


321 The average estimate of absolute somatic growth rate for larvae $<25 \mathrm{~mm}\left(0.38 \mathrm{~mm} \mathrm{~d}^{-1}\right)$ is the same

322 as estimated by Castonguay (1987) in his study, while it is somewhat above the estimate by Kuroki 323 et al. (2017) of $0.31 \mathrm{~mm} \mathrm{~d}^{-1}$. Compared to estimates for other species of the genus Anguilla (range:

$3240.35-0.59 \mathrm{~mm} \mathrm{~d}^{-1}$; Tsukamoto, 1992; Arai et al., 2000; Kuroki et al., 2006, 2007) the estimates for 325 A. anguilla are all in the lower range. A number of non-anguillid eels, and elopomorph leptocephali 326 have also been shown to have quite high growth rates (range: $0.63-1.42 \mathrm{~mm} \mathrm{~d}^{-1}$; Crabtree et al., 327 1992; Bishop et al., 2000). The higher growth rates cited were obtained in relatively warm waters, 328 and temperature is likely the main cause of differences among values.

329 We assessed the potential seasonal variation in growth from the rates during the first 10 days of life 330 based on the otolith widths for that period. We found a negative correlation of early growth rates 331 with estimated spawning dates (Fig. 7); thus, specimens spawned earlier in the year showed higher 332 average initial growth rates. The magnitude of this seasonal variation was, however, small relative 333 to the substantially large overall variation in growth for larvae with the same spawning dates. There 334 is no straightforward explanation for this weak temporal trend; it appears not simply to linked to 335 primary productivity changes, while the productivity in the Sargasso area generally is increasing 336 during the period January to April (Mentzel \& Ryther 1961).

337 We anticipated that the hydrographically variable environment of the STCZ would lead to a 338 significant spatial variability in the growth of eel larvae distributed across it. However, we found 339 only a weak spatial trend in one of the two measures we used for larval growth: lengths at age and 340 average width of the first otolith increments. The measure of initial growth rate tended to decline 341 towards the north in the area, a tendency which might relate to the seasonal effect on this index, 342 irrespective that we could not deduce consistent north-south trends in our estimates of average 343 spawning time (Fig. 1c). The part of variability we could ascribe to spatial, temporal or 344 oceanographic measures were in any case minor compared to the prominent, non-explained, 
variability in larval growth rates at single sites. Large growth variability was seen on a local scale

346 (i.e. within few kilometers) while potential larger-scale changes (10-100 kilometers) did not add

347 further to this variability. It should be noted, however, that the significant mixing of larger water 348 masses due to the prominent eddies could be partly responsible for blurring potential directional

349 tendencies on the actual scale. Along the longitudinal axes the eddy patterns are quite repetitive, 350 and on the mesoscale $(\sim 100 \mathrm{~km})$ we see basically the same hydrographic patterns from west to east 351 across the area of larval distribution.

\section{Conclusions and Perspectives}

353 Our findings of wide individual variability in both age and growth rates of European eel larvae at 354 given restricted locations, combined with a lack of clear spatial trends in average growth rates 355 across the vast area of larval distribution, point to several remarkable characteristics of the spawning and early life of European eel. Spawning is protracted in time and space, and the large variability in ages at given locations indicates that several spawning events had taken place within restricted areas, possibly by multiple spawnings of individual females. Due to the differences in time of spawning, and apparently also due to local variability in the hydrographic and biological environments, marked differences in life trajectories of individual larvae were apparent within 361 relatively restricted areas. The large variability in growth rates shows that most larvae are far from optimal growth, indicating that conditions for early life are harsh at any given location in the STCZ.

363 On the other hand, the average opportunities for larval life across the $2000 \mathrm{~km}$ wide area used for 364 spawning by European eels did not differ significantly. Thus, the species has a huge area available, 365 the STCZ, with conditions which can support the early life, and the spawners apparently need not 366 direct their migration and spawning to specific longitudes along the STCZ in order to further 367 promote growth opportunities of their larvae. Our study showed a decline in growth rate for the older larvae that are still distributed in the STCZ. Further changes in growth is to be expected when 
369 larvae leave the STCZ and face other environmental conditions during their drift towards the

370 European continent, and the present findings encourage continued studies incorporating these later 371 phases of the larval life.

\section{Acknowledgements}

375 This study was supported by the Carlsberg Foundation, Denmark (2012_01_0272), and the Danish

376 Centre for Marine Research (2013_02). The authors have no conflicts of interest related to the 377 presented work. We gratefully acknowledge Berit Wenzell, Ane P. Rollan, Michael M. Hansen and 378 Line Andersen for their help during otolith and sample processing. We also thank colleagues and 379 the crew of the Danish research vessel, DANA, for their helpful assistance during the field 380 sampling. 


\section{References}

Aarestrup, K., Økland, F., Hansen, M. M., Righton, D., Gargan, P., Castonguay, M., Bernatchez, L., Howey, P., Sparholt, S., Pedersen, M. I. \& McKinley, R. S. (2009). Oceanic Spawning Migration of the European Eel (Anguilla anguilla). Science 325: 1660-1661. Bernatchez, L. (2011). All roads lead to home: panmixia of European eel in the Sargasso Sea. Mol. Ecol. 20(7): 1333-1346. Sci. Rep. 6: 21817. (doi:10.1038/srep21817)

Andersen, N.G., Nielsen, T.G., Jakobsen, H.H., Munk, P. \& Riemann, L. (2011). Distribution and production of plankton communities in the subtropical convergence zone of the Sargasso Sea. II.

395 Protozooplankton and copepods. Mar. Ecol. Prog. Ser. 426:71-86.

Arai, T., Otake, T., Limbong, D. \& Tsukamoto, K. (1999). Early life history and recruitment of the tropical eel Anguilla bicolor pacifica, as revealed by otolith microstructure and microchemistry. Mar. Biol. 133(2): 319-326. (doi:10.1007/s002270050470) 
Bishop, R.E., Torres, J.J. \& Crabtree, R.E. (2000). Chemical composition and growth indices in 403 leptocephalus larvae. Mar. Biol. 137(2): 205-214. (doi:10.1007/s002270000362)

404 405 406 407 408 409 410

Boëtius, I \& Boëtius, j. (1980). Experimental maturation of female silver eels, Anguilla anguilla. Estimates of fecundity and energy reserves for migration and spawning. Dana. 1: 1-28.

Boëtius, J. \& Harding, E. F. (1985). A re-examination of Johs Schmidt's eel investigation. Dana 4: 129-162.

Bouilliart, M., Tomkiewicz, J., Lauesen, P., Kegel, B.D. \& Adriaens, D. (2015). Musculoskeletal anatomy and feeding performance of pre-feeding engyodontic larvae of the European eel (Anguilla anguilla). J. Anat. 227: 325-340.

Butts, I. A. E., Sørensen, S. R., Politis, S. N. \& Tomkiewicz, J. (2016). First-feeding by European eel larvae: A step towards closing the life cycle in captivity. Aquaculture. 464: 451-458.

Castonguay, M. (1987). Growth of American and European eel leptocephali as revealed by otolith microstructure. Can. J. Zool. 65: 875-878.

Castonguay, M., \& McCleave, J. D. (1987). Vertical distributions, diel and ontogenetic vertical migrations and net avoidance of leptocephali of Anguilla and other common species in the Sargasso Sea. J. Plankton Res., 9(1), 195-214.

Cieri, M.D. \& McCleave, J. D. (2001). Validation of daily otolith increments in glass-phase American eels Anguilla rostrata (Lesueur) during estuarine residency. J. Exp. Mar. Biol. Ecol. 257(2): 219-227. (doi:10.1016/S0022-0981(00)00333-6. PMID:11245877) 
Correia, A. T., Isidro, E. J., Antunes, C. \& Coimbra, J. (2002). Age, growth, distribution and ecological aspects of Conger conger leptocephali collected in the Azores, based on otolith analysis of premetamorphic specimens. Mar. Biol. 141: 1141-1151. of Tarpon, Megalops atlanticus, larvae in the eastern Gulf of Mexico, with notes on relative abundance and probable spawning area. Env. Biol. Fish 35: 361-370.

Deibel, D., Parrish, C. C., Grønkjær, P., Munk, P., \& Nielsen, T. G. (2012). Lipid class and fatty acid content of the leptocephalus larva of tropical eels. Lipids, 47(6): 623-634.

Fukuda, N., Kuroki, M., Shinoda, A., Yamada, Y., Okuamura, A., Aoyama, J. \& Tsukamoto, K. 431 (2009). Influence of water temperature and feeding regime on otolith deposition in Anguilla japonica glass eels: Evidence of deposition cessation at low temperature. J. Fish Biol. 74: 19131933.

Goodhew, P. J., Humphreys, J., \& Beanland, R. (2000). Electron microscopy and analysis. CRC 435 Press.

Ishikawa, S., Suzuki, K., Inagaki, T., Watanabe, S., Kimura, Y., Okamura, A., Otake, T., Mochioka, 437 N., Suzuki, Y., Hasumoto, H., Oya, M., Miller, M.J., Lee, T.W., Fricke, H. \& Tsukamoto, K. 438 (2001). Spawning time and place of the Japanese eel, Anguilla japonica, in the North Equatorial 439 Current of the western North Pacific Ocean. Fish. Sci. 67(6): 1097-1103. (doi:10.1046/j.1444$440 \quad 2906.2001 .00366 . x)$

441 Jacobsen, M. W., Smedegaard, L., Sørensen, S. R., Pujolar, J. M., Munk, P., Jónsson, B., 442 Magnussen, E. \& Hansen, M. M. (2016). Assessing pre-and post-zygotic barriers between North 
443 Atlantic eels (Anguilla anguilla and A. rostrata). Heridity 118: 266-275

$444 \quad$ (doi.org/10.1038/hdy.2016.96)

445 Kleckner, R. C. \& McCleave, J. D. (1988). The northern limit of spawning by Atlantic eels 446 (Anguilla spp.) in the Sargasso Sea in relation to thermal fronts and surface water masses. J. Mar. 447 Res. 46: 647-667.

448 Kuroki, M., Aoyama, J., Miller,M. J., Wouthuyzen, S., Arai, T., Tsukamoto, K. (2006). Contrasting 449 patterns of growth and migration of tropical Anguillid leptocephali in the western Pacific and 450 Indonesian Seas. Mar. Ecol. Prog. Ser. 309: 233-246.

451 Kuroki, M., Aoyama, J., Wouthuyzen, S., Sumardhiharga, K., Miller, M.J. \& Tsukamoto, K. 452 (2007). Age and growth of Anguilla bicolor bicolor leptocephali in the eastern Indian Ocean. $J$. 453 Fish Biol. 70(2): 538-550. (doi:10.1111/j.1095-8649.2007.01324.x)

454 Kuroki, M., Aoyama, J., Miller, M. J., Watanabe, S., Shinoda, A., Jellyman, D. J., Feunteun, E. \& 455 Tsukamoto, K. (2008). Distribution and early life-history characteristics of anguillid leptocephali in 456 the western South Pacific. Mar. Freshw. Res., 59(12): 1035-1047

457 Kuroki, M., Miller, M. J. \& Tsukamoto, K. (2014). Diversity of early life-history traits in 458 freshwater eels and the evolution of their oceanic migrations. Can. J. Zool. 92: 749-770. 459 (doi.org/10.1139/cjz-2013-0303)

460 Kuroki, M., Marohn, L., Wysujack, K., Miller, M. J., Tsukamoto, K., \& Hanel, R. (2017). Hatching 461 time and larval growth of Atlantic eels in the Sargasso Sea. Mar. Biol., 164(5): 118.

463 Laird, A. K. (1969). Dynamics of growth in tumors and in normal organisms. National Cancer 464 Institute Monograph, 30: 15. 

metamorphosis timing and the larval growth rate on the latitudinal distribution of sympatric

467 freshwater eels, Anguilla japonica and A. marmorata, in the western North Pacific. Zool. Stud. $468 \quad 52: 30$

469 Lecomte-Finiger, R. (1992). Growth history and age at recruitment of European glass eels (Anguilla 470 anguilla) as revealed by otolith microstructure. Mar. Biol. 114: 205-210.

471 Lee, T. W., Miller, M. J., Hwang, H. B., Wouthuyzen, S. \& Tsukamoto, K. (2008). Distribution and 472 early life history of Kaupichthys leptocephali (family Chlopsidae) in the central Indonesian Seas. 473 Mar. Biol. 153:285-295 (doi: 10.1007/s00227-007-0804-z).

474 Ma, T., Miller M. J., Shinoda A, Minagawa G., Aoyama J. \& Tsukamoto K. (2005). Age and 475 growth of Saurenchelys (Nettastomatidae) and Dysomma (Synaphobranchidae) leptocephali in the 476 East China Sea. J. Fish Biol. 67: 1619-1630.

477 Martin, M. H. (1995). Validation of daily growth increments in otoliths of Anguilla rostrata 478 (Lesueur) elvers. Can. J. of Zoo. 73: 208-211.

479 McCleave, J.D. \& Kleckner, R. C. (1987). Distribution of leptocephali of the catadromous Anguilla 480 species in the western Sargasso Sea in relation to water circulation and migration. Bull. Mar. Sci. $481 \quad 41: 789-806$.

482 Menzel, D. W., \& Ryther, J. H. (1961). Annual variations in primary production of the Sargasso Sea 483 off Bermuda. Deep Sea Research, 7(4): 282-288.

484 Miller, M. J. (2009). Ecology of anguilliform leptocephali: remarkable transparent fish larvae of the 485 ocean surface layer. Aqua-BioScience Monographs 2: 1-94. 
Miller, J. M., Bonhommeau, S., Munk, P., Castonguay, M., Hanel, R. \& McCleave, J. D. (2015). A century of research on the larval distributions of the Atlantic eels: a re-examination of the data. Biol. Rev. 90: 1035-1064.

Munk, P., Hansen, M.M., Maes, G.E., Nielsen, T.G., Castonguay, M., Riemann, L., Sparholt, H., Als, T.D., Aarestrup, K., Andersen N.G. \& Bachler, M. (2010). Oceanic fronts in the Sargasso Sea control the early life and drift of atlantic eels. Proc. R. Soc. Lond. B. 277: 3593-3599.

Pankhurst, N. (1982). Relation of visual changes to the onset of sexual maturation in the European eel Anguilla anguilla (L.). J. Fish Biol. 21: 127-140. (doi: 10.1111/j.1095-8649.1982.tb03994.x)

Politis, S. N., Mazurais, D., Servili, A., Zambonino-Infante, J. L., Miest, J. J., Sørensen, S. R., Tomkiewicz, J. \& Butts, I. A. (2017). Temperature effects on gene expression and morphological development of European eel, Anguilla anguilla larvae. PloS one, 12(8), (doi.org/10.1371/journal.pone.0182726)

Richardson, K., \& Bendtsen, J. (2017). Photosynthetic oxygen production in a warmer ocean: the Sargasso Sea as a case study. Phil. Trans. R. Soc. A, 375(2102): 201

Riemann, L. R., Alfredsson, H., Hansen,M. M., Als, T. D., Nielsen, T. G., Munk, P., Aarestrup, K., Maes, G. E., Sparholt, H., Petersen, M. I., Bachler, M. \& Castonguay, M. (2010). Qualitative assessment of the diet of European eel larvae in the Sargasso Sea resolved by DNA barcoding. Biol. Lett. 6: 819-822. (doi:10.1098/rsbl.2010.0411)

Schabetsberger, R., Miller, M. J., Olmo, G. D., Kaiser, R., Økland, F., Watanabe, S., \& Tsukamoto, K. (2016). Hydrographic features of anguillid spawning areas: potential signposts for migrating eels. Marine Ecology Progress Series, 554: 141-155. 
508 Schmidt, J. (1925). The breeding places of the eel. Annual Report of the Smithsonian Institute 1924: $509 \quad 279-316$.

510 Schmidt, J. (1935). Danish Eel Investigations during 25 Years (1905-1930). Carlsberg Foundation, 511 Copenhagen.

512 Shinoda, A., Tanaka, H., Kagawa, H., Ohta, H. \& Tsukamoto, K. (2004). Otolith microstructural 513 analysis of reared larvae of the Japanese eel Anguilla japonica. Fish. Sci. 70(2): 340-342. 514 (doi:10.1111/j.1444-2906.2003.00810.x)

515 Shinoda, A., Aoyama, J., Miller, M.J., Otake, T., Mochioka, N., Watanabe, S., Minegishi, Y., 516 Kuroki, M., Yoshinaga, T., Yokouchi, K., Fukuda, N., Sudo, R., Hagihara, S., Zenimoto, K., 517 Suzuki, Y., Oya, M., Inagaki, T., Kimura, S., Fukui, A., Lee, T.W. \& Tsukamoto, K. (2011). 518 Evaluation of the larval distribution and migration of the Japanese eel in the western North Pacific. 519 Rev. Fish Biol. Fish. 21(3): 591-611. (doi:10.1007/s11160-010-9195-1)

520 Sugeha, H.-Y., Shinoda, A., Marui, M., Arai, T. \& Tsukamoto, K. (2001). Validation of otolith 521 daily increments in the tropical eel Anguilla marmorata. Mar. Ecol. Prog. Ser. 220: 291-294. 522 (doi:10.3354/meps220291)

523 Sørensen, S. R., Tomkiewicz, J., Munk, P., Butts, I. A. E., Nielsen, A., Lauesen, P. \& Graver, C. 524 (2016). Ontogeny and growth of early life stages of captive-bred European eel. Aquaculture 456: $525 \quad 50-61$

526 Tesch, F. (2003). The eel. Blackwell Science Ltd., Oxford, UK. 
527 Tomkiewicz, J. \& Jarlbæk, H. (2008). Kunstig reproduktion af ål: Roe II og IIB. Technical

528 University of Denmark, Institute for Aquatic Resources. DTU-Aqua report 180-08. 79 pp.

529 Tomkiewicz, J., Støttrup, J.G., Corraze, G., Kausik, S., Holst, L.K., McEvoy, F., Dufour, S., Lafont, 530 A.-G., Asturiano, J.F., Sørensen, S.R., Tveiten, H., De Schryver, P., Butts, I.A.E., Munk, P., 531 Zambonino, J.I., Politis, S.N., Johnsen, M.K. \& Lauesen, P. (2013). Reproduction of European eel 532 and larval culture: state of the art. Commun. Agric. Appl. Biol. Sci. 78: 455-456.

533 Tsukamoto, K. (1992). Discovery of the spawning area for Japanese eel. Nature 356: 789-791.

534 Tsukamoto, K. (2006). Spawning of eels near a seamount. Nature, 439: 929. (doi:10.1038/439929a)

535 Tsukamoto, K. (2009). Oceanic migration and spawning of anguillid eels. J. Fish. Biol. 74(9): 536 1833-1852. (doi:10.1111/j.1095-8649.2009.02242.x.)

537 Tsukamoto, K., Aoyama, J., \&Miller, M.J. (2002). Migration, speciation, and the evolution of 538 diadromy in anguillid eels. Can. J. Fish. Aquat. Sci. 59(12): 1989-1998. (doi:10.1139/f02-165)

539 Tsukamoto, K., Otake, T., Mochioka, N., Lee, T.-W., Fricke, H., Inagaki, T., Aoyama, J., Ishikawa, 540 S., Kimura, S., Miller, M. J., Hasumoto, H., Oya, M. \& Suzuki, Y. (2003). Seamounts, New Moon 541 and eel Spawning: The Search for the Spawning Site of the Japanese eel. Env. Bio. Fishes 66(3): $542 \quad 221-229$.

543 Umezawa, A., Tsukamoto, K., Tabeta, O. \& Yamakawa, H. (1989). Daily growth increments in the 544 larval otolith of the Japanese eel, Anguilla japonica. Jpn. J. Ichthyol. 35(4): 440-444.

545 (doi:10.1007/BF02905501) 
546 Umezawa, A. \& Tsukamoto, K. (1991). Factors influencing otolith increment formation in Japanese 547 eel, Anguilla japonica T. \& S., elvers. J. Fish. Biol. 39(2): 211-223. (doi:10.1111/j.1095548 8649.1991.tb04357.x)

549 Wang, C. H. \& Tzeng, W. N. (2000). The timing of metamorphosis and growth rates of American 550 and European eel leptocephali: a mechanism of larval segregative migration. Fish. Res. 46: 191551205. 
553

\begin{tabular}{|c|c|c|c|c|c|c|c|c|}
\hline \multirow{2}{*}{ Transect } & \multirow{2}{*}{$\begin{array}{c}\text { Sampling } \\
\text { period }\end{array}$} & \multirow{2}{*}{$\begin{array}{c}\text { Longitude } \\
\text { (degrees } \mathrm{W})\end{array}$} & \multirow{2}{*}{$\begin{array}{c}\text { Latitude range of } \\
\text { sampled larvae } \\
(\text { degrees } \mathrm{N})\end{array}$} & \multirow{2}{*}{$\begin{array}{c}\text { Larvae } \\
\text { analyzed } \\
(\text { no) }\end{array}$} & \multicolumn{2}{|c|}{$\begin{array}{c}\text { Standard length } \\
(\mathrm{mm})\end{array}$} & \multicolumn{2}{|c|}{$\begin{array}{c}\text { Otolith diameter } \\
(\mu \mathrm{m})\end{array}$} \\
\hline 1 & $18 / 3-21 / 3$ & $68^{\circ} 30^{\prime}$ & $30^{\circ} 00^{\prime}-25^{\circ} 00^{\prime}$ & 28 & 8.0 & 18.4 & 22.6 & 48.2 \\
\hline 2 & $22 / 3-25 / 3$ & $65^{\circ} 30^{\prime}$ & $28^{\circ} 30^{\prime}-25^{\circ} 00^{\prime}$ & 19 & 7.2 & 16.5 & 22.1 & 39.8 \\
\hline 3 & $26 / 3-5 / 4$ & $62^{\circ} 45^{\prime}$ & $29^{\circ} 50^{\prime}-24^{\circ} 40^{\prime}$ & 115 & 7.3 & 34.2 & 23.5 & 132.8 \\
\hline 4 & $9 / 4-10 / 4$ & $59^{\circ} 30^{\prime}$ & $27^{\circ} 30^{\prime}-25^{\circ} 40^{\prime}$ & 16 & 11.8 & 19.7 & 30.1 & 60.0 \\
\hline 5 & $11 / 4-12 / 4$ & $57^{\circ} 00^{\prime}$ & $28^{\circ} 20^{\prime}-26^{\circ} 30^{\prime}$ & 15 & 8.9 & 17.5 & 27.4 & 39.6 \\
\hline 6 & $13 / 4-14 / 4$ & $53^{\circ} 30^{\prime}$ & $28^{\circ} 30^{\prime}-27^{\circ} 20^{\prime}$ & 17 & 6.3 & 24.7 & 27.7 & 67.0 \\
\hline 7 & $15 / 4-16 / 4$ & $50^{\circ} 00^{\prime}$ & $27^{\circ} 20^{\prime}-26^{\circ} 20^{\prime}$ & 13 & 9.0 & 19.7 & 25.5 & 41.5 \\
\hline
\end{tabular}

Table 1 


\section{Legends to figures}

557 Figure 1. a) Locations of stations in the Sargasso Sea sampled during March-April 2014 by the

558 Danish Eel Expedition. Transects are numbered 1-9. Rectangle encloses area shown in b) and c). b)

559 Mean lengths of $A$. anguilla larvae illustrated for all stations were these larvae were sampled;

560 symbols indicate length intervals $(\mathrm{mm})$ as in legend to the right. Symbols are imposed on an

561 isopleth map of measured temperature at $50 \mathrm{~m}$ depth, isotherms show temperature in $0.25^{\circ} \mathrm{C}$

562 intervals, c) Mean ages of $A$. anguilla larvae estimated for the $1^{\text {st }}$ April; symbols illustrate age

563 intervals (d) as in legend to the right. Symbols are imposed on an isopleth map of measured

564 temperature at $150 \mathrm{~m}$ depth, isotherms show temperature in $0.25^{\circ} \mathrm{C}$ intervals.

565 Figure 2: A. anguilla. Scanning electron microscopy images of sagittal otoliths from two specimens.

566 a) otolith from a $23.0 \mathrm{~mm}$ leptocephalus, b) otolith from a $14.9 \mathrm{~mm}$ leptocephalus, c) illustration of 567 the hatch check (HC), first-feeding check (FFC) and the crystalline core (CC) from the $23.0 \mathrm{~mm}$ 568 leptocephalus.

569 Figure 3. A. anguilla. Relationships between larval length $(\mathrm{mm})$ and otolith sagitta measures $(\mu \mathrm{m})$.

570 Upper curve (filled circles) illustrates relationship to maximal diameter of otolith (OD), lower curve 571 (open triangles) illustrates distances along radius measured from start of ring formation at FFC to 572 the edge of otolith (ORF). Curves are nonlinear fits as indicated by the equations.

573 Figure 4. A. anguilla. Contributions of leptocephali $(\mathrm{n}=208)$ from spawning on back-calculated 574 dates (as percent within a day of year or a calendar date). Thirteen pre-leptocephali not exhibiting 575 otolith growth increments, hence with uncertain spawning dates, and 2 leptocephali with spawning 576 dates on January 20 and December 8 (2013) are not included). Moon phases illustrated with 
pictograms along the top axis: black circles are new moons, light circles full moons. a) direct backcalculations, b) distributions re-calculated with incorporation of natural mortality and an even sampling coverage

Figure 5. A. anguilla. Relationships between otolith increments and length measures. a) Larval 581 length versus increments, larvae from all stations. b) As for a), but only for larvae from station 30, 582 c) As for a), only for larvae $<=25 \mathrm{~mm}$. d) Maximal otolith diameter $(\mu \mathrm{m})$ versus increments. Curves 583 are fitted Laird-Gompertz curves ( $\mathrm{a}$ and $\mathrm{b}$ ), or linear regressions ( $\mathrm{b}$ and $\mathrm{d}$ ), regression equations and $584 \quad r^{2}$ values are inserted in the graphs. Prediction and confidence bands illustrated by line types listed 585 upper left in a).

586 Figure 6. A. anguilla. Spatial variation in growth rate estimates of leptocephali. a-b) Growth rate in 587 length ( $\left.\mathrm{mm} \mathrm{d}^{-1}\right)$ during period from hatching to catch, related to $\mathrm{c}$ ) sampling longitude or d) 588 sampling latitude. c-d) Growth in otolith radius $(\mu \mathrm{m})$ during the first 10 days after first feeding, 589 related to a) sampling longitude and b) sampling latitude.

590 Figure 7. A. anguilla. Growth in larval otolith radius $(\mu \mathrm{m})$ during the first 10 days after first 591 feeding, plotted along an axis representing estimated date of spawning. Closed symbols denote all 592 available data $(\mathrm{n}=147)$. Open circles indicate larvae from just station $30(\mathrm{~N}=53)$. Linear regressions 593 for all data, and for station 30 data only, are shown by hatched and full lines, respectively. 
a)

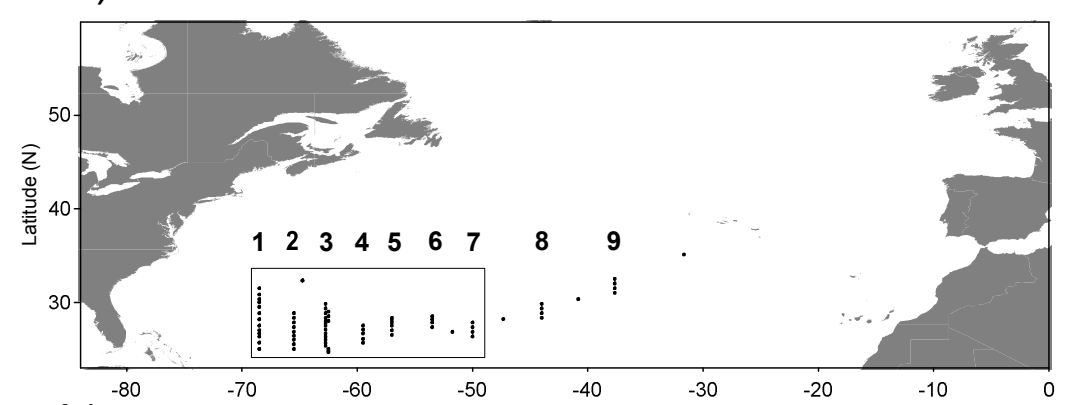

b)

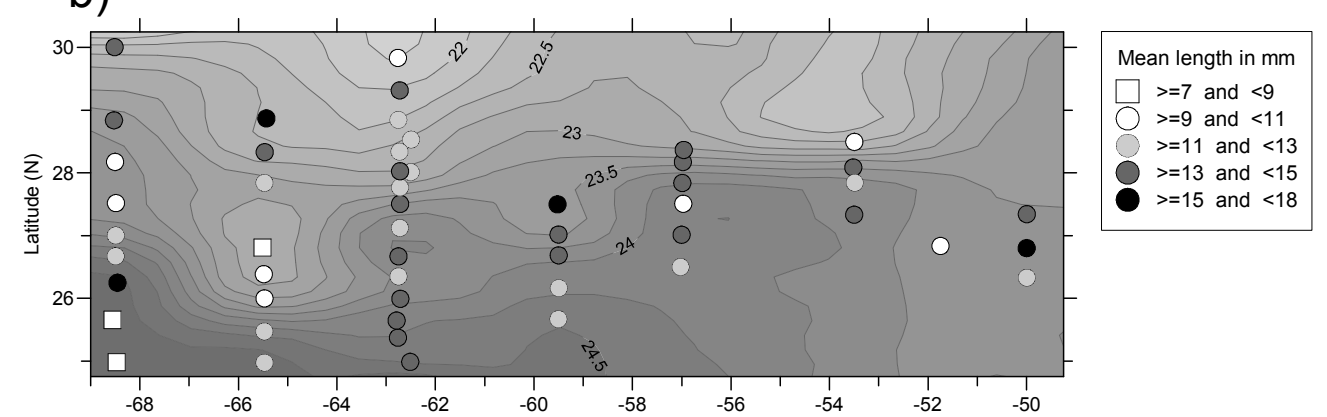

c)

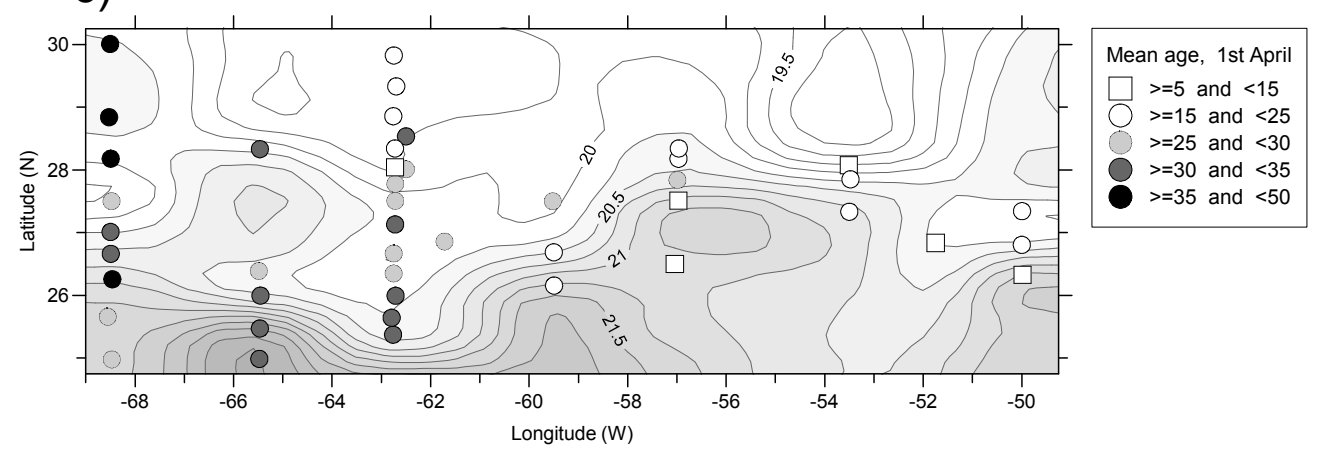

596 Fig. 1. 
a)

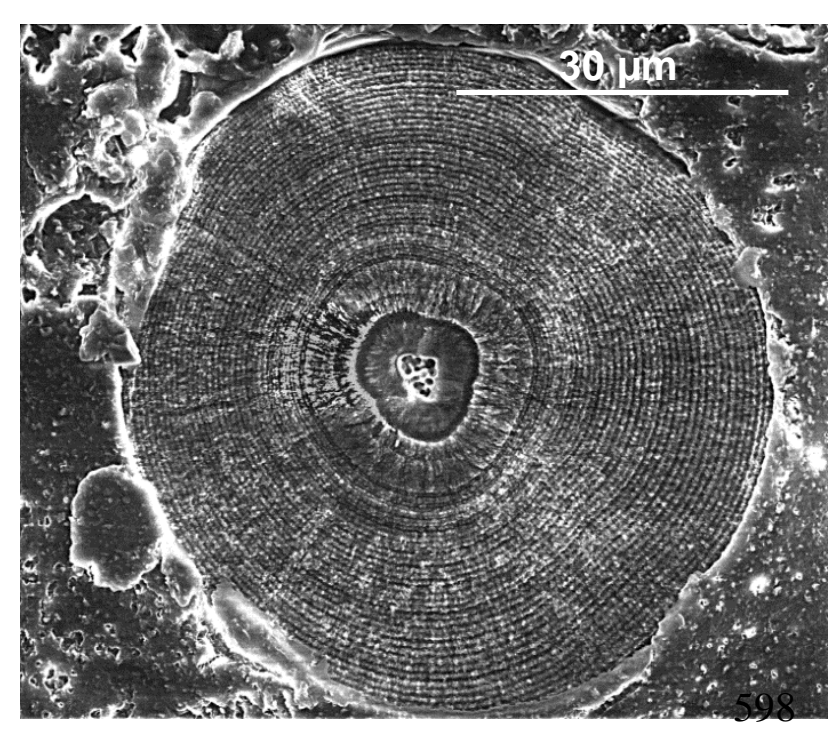

b)

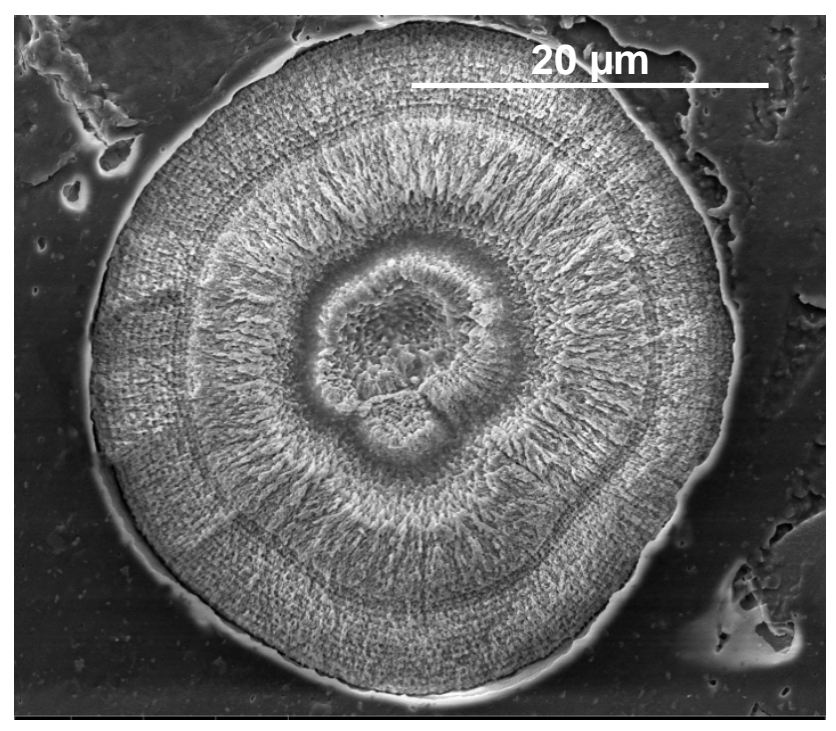

c)

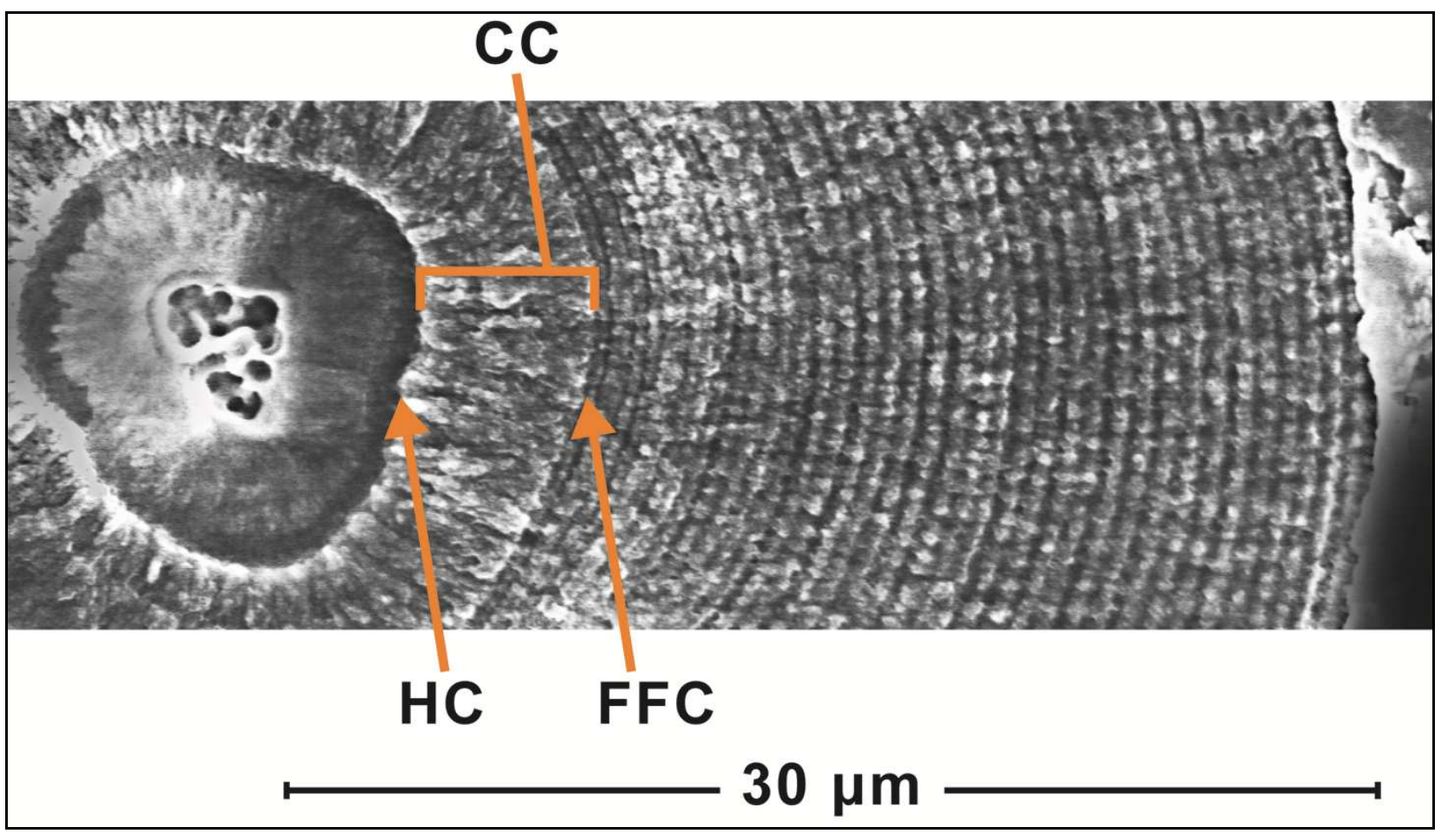

$601 \quad$ Fig. 2 


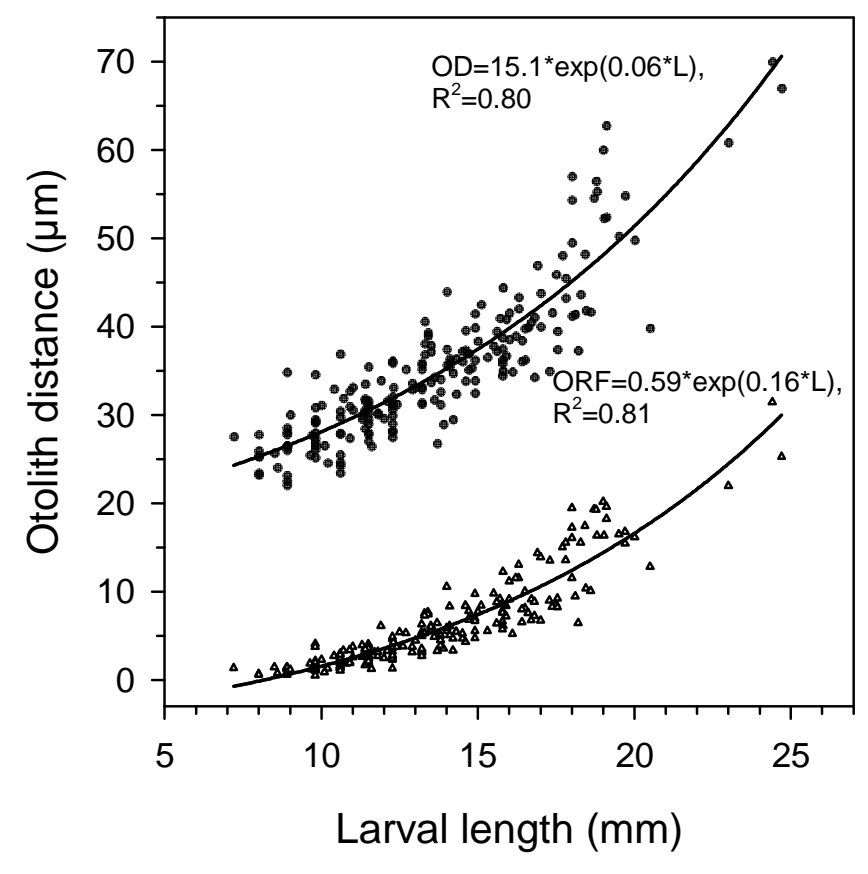

603 Fig. 3

604 
a)

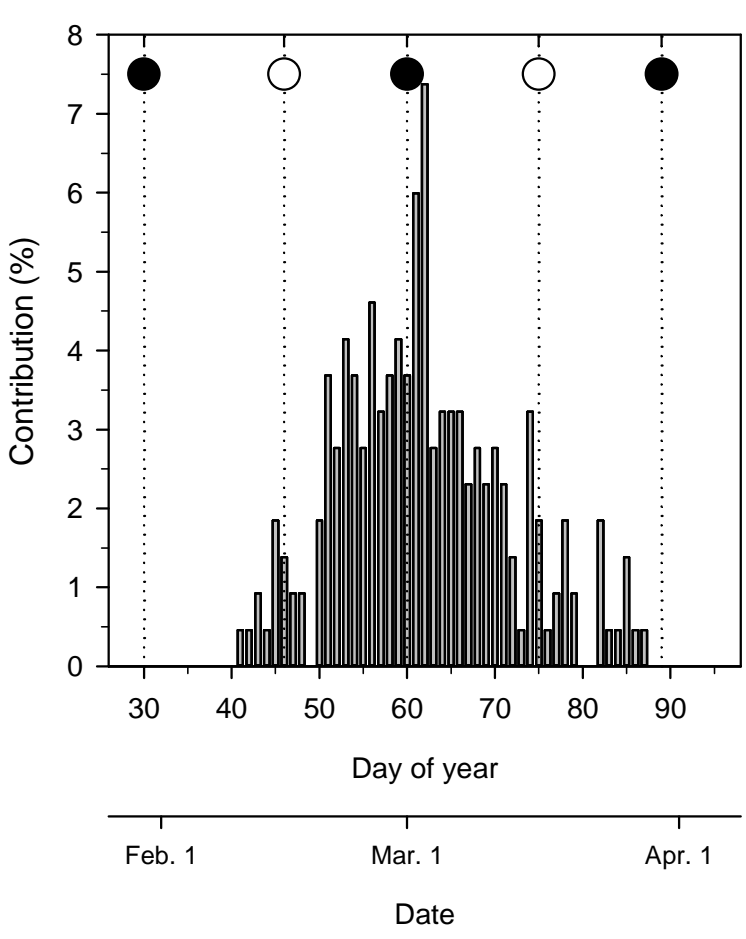

b) Phase of moon

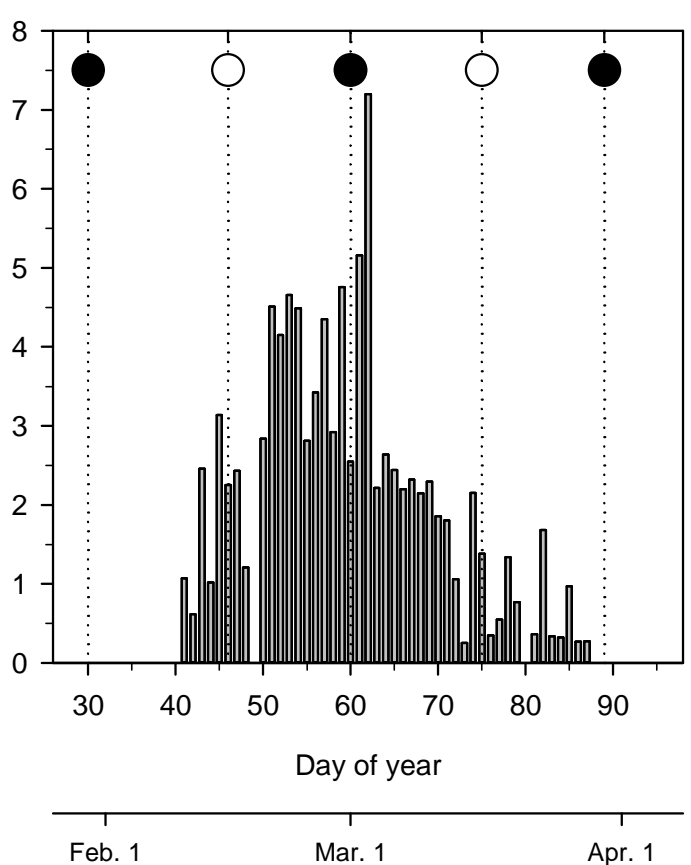

Date

605

Fig 4 
a)
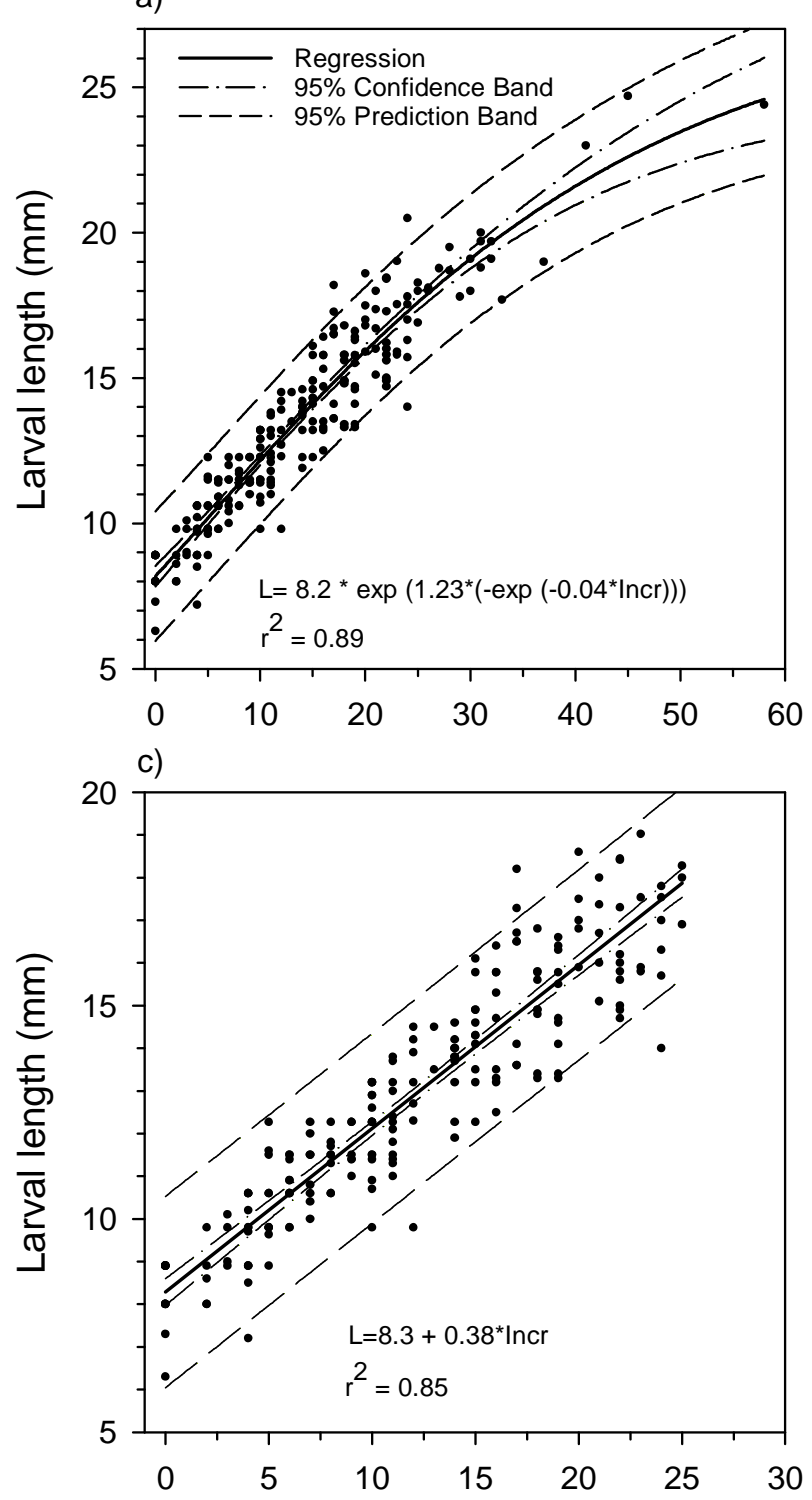

Increments b)
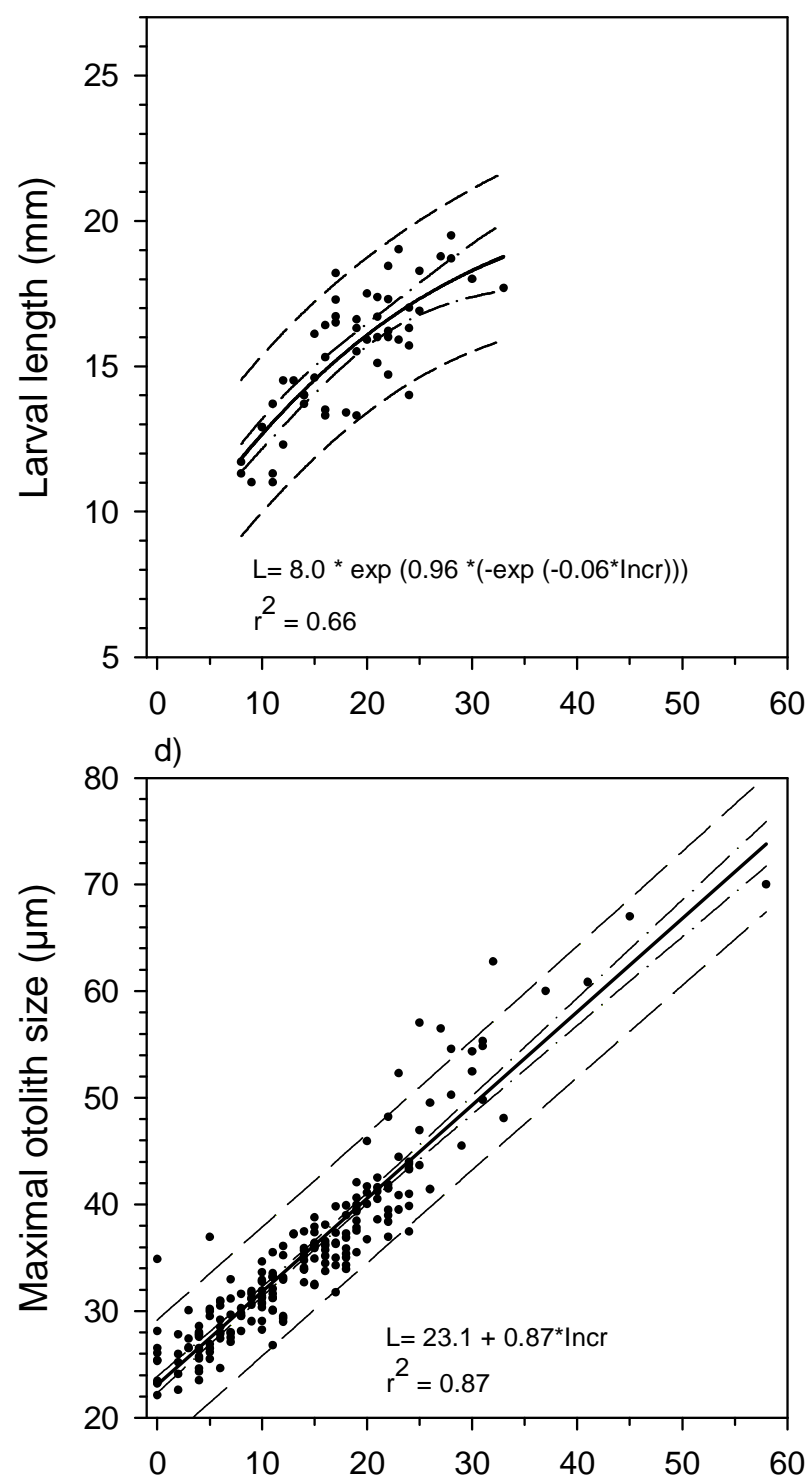

Increments

Fig. 5 

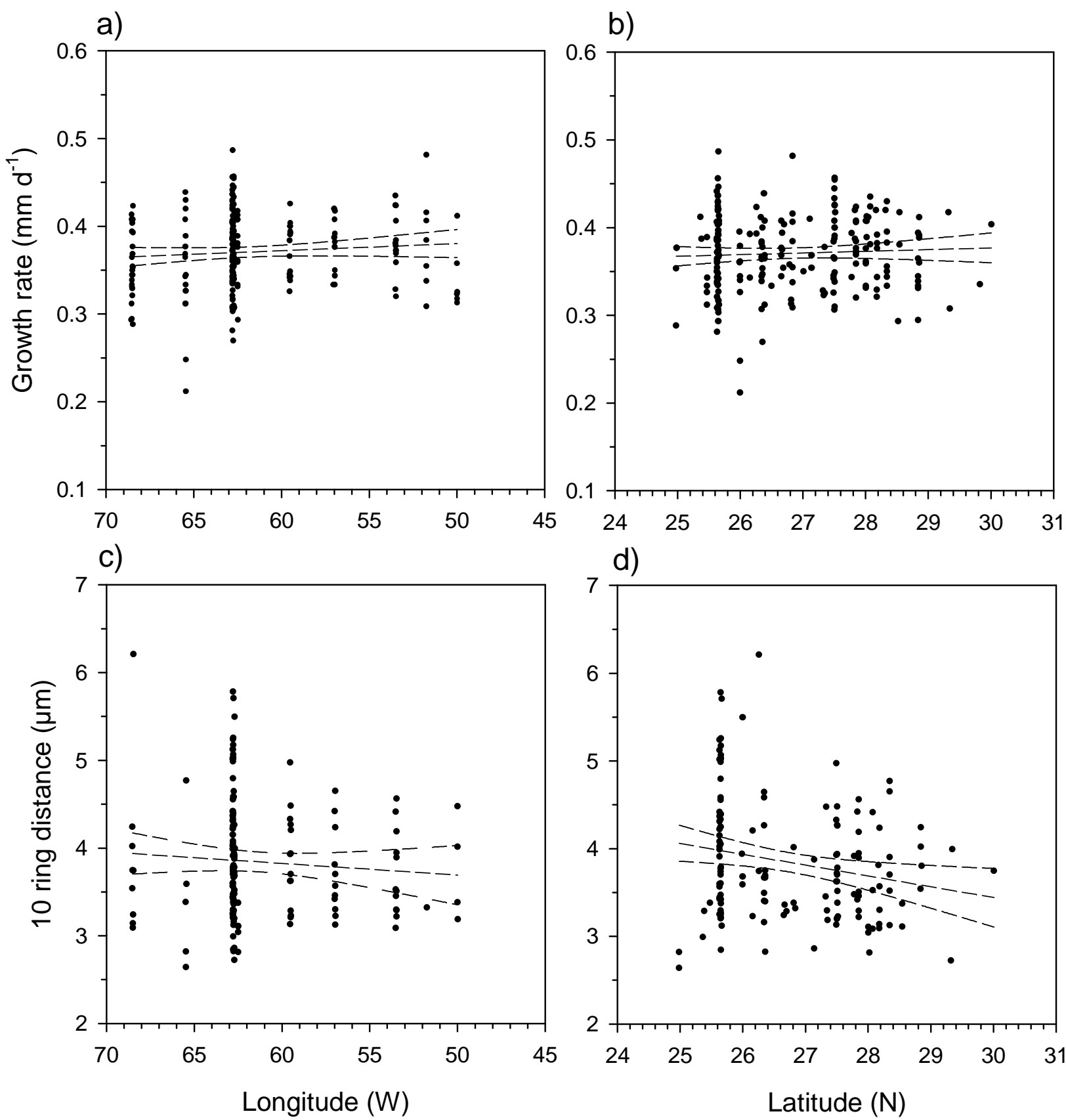

d)

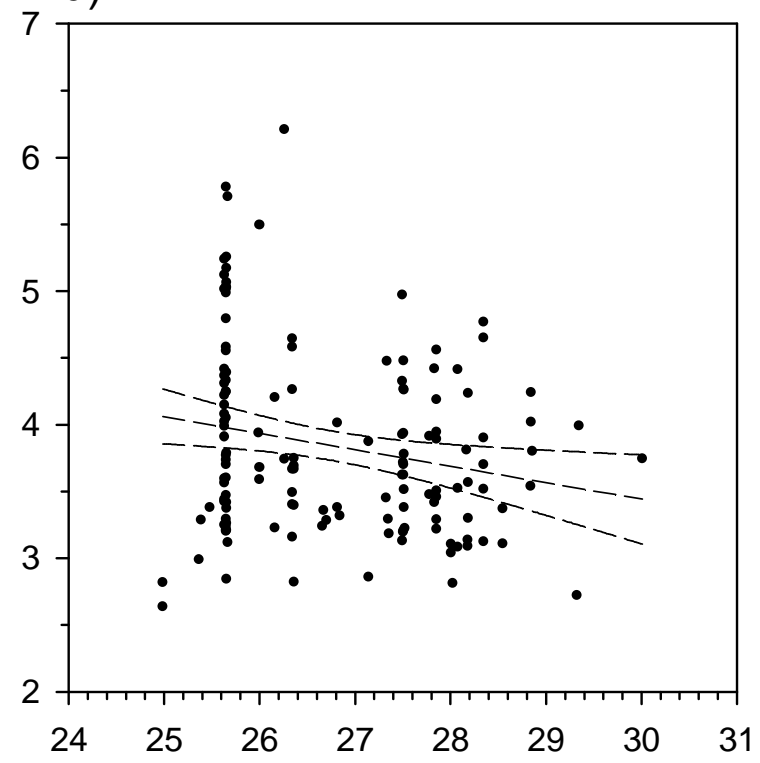

610

Fig. 6

612 


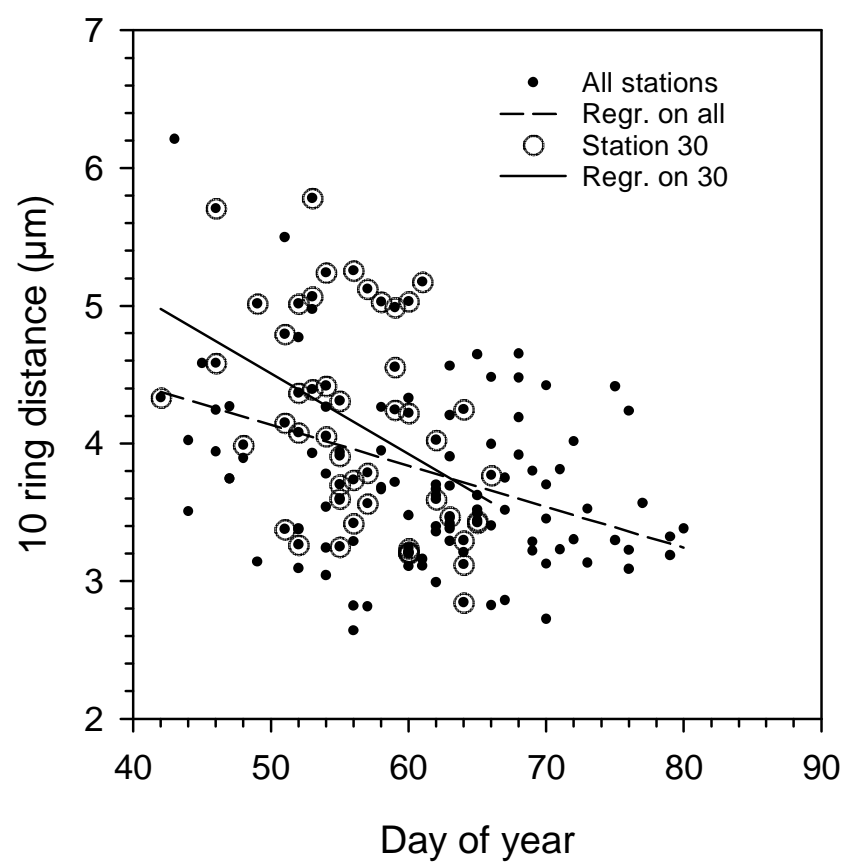

613.

614 Fig. 7

615 